\title{
DIFFERENCES IN ERGOCALCIFEROL CONTENT AND SOME AGRONOMIC CHARACTERS AMONG GROWTH STAGES IN SIX FIELD PEA GENOTYPES
}

\author{
Ertan Ates ${ }^{1, *}$, Hazim Serkan Tenikecier ${ }^{1}$ \\ ${ }^{1}$ Tekirdag Namik Kemal University, Agriculture Faculty, \\ Field Crops Department, 59030, Suleymanpasa-Tekirdag, Turkey
}

Current Trends in

Natural Sciences

\begin{abstract}
The aim of this research was to determine the effect of different growth stages on ergocalciferol content, yield, some morphological characters and forage quality properties of six field pea genotypes (Töre, Ateş, Taşkent, 16-K, DYK and $K r)$. Genotypes were planted in two-factor factorial randomized block design with three replications. Some morphological characters (main stem length, number of branches per plant, number of leaves per main stem and leaf length), herbage and hay yields, ergocalciferol, crude protein, crude fiber, acid detergent fiber, acid detergent lignin and neutral detergent fiber contents were determined at the pre-bud, 1/4 bloom and full-bloom stages. The maximum

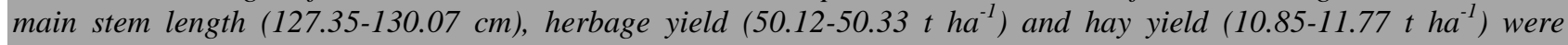
observed from field pea genotypes 'Ateş' and 'Töre' at full-bloom stage. The lowest leaf length (22.08 cm) and number of leaves per main stem (20.09) were found in field pea genotype '16-K', whereas number of branches per plant (6.42) had its highest in same genotype. Full-bloom stage showed the highest ergocalciferol (9.33 $\mu \mathrm{g} \mathrm{kg}^{-1}$ in fresh matter), crude fiber $(20.63 \%)$, neutral detergent fiber (41.46\%), acid detergent fiber (30.54\%) and acid detergent lignin (5.84 $\%)$ contents between the other growth stages, whereas crude protein (18.37\%) had its lowest content at same growth stage. According to ergocalciferol content, forage yield and other quality properties, genotypes 'Ateş' and 'Töre' can be sown and cut at full-bloom stage in the Thrace and other regions of Turkey, and probably in similar subtropical conditions.
\end{abstract}

Keywords: ergocalciferol, field pea, forage yield, morphological characters, Pisum arvense L., vitamin $\mathrm{D}_{2}$

\section{INTRODUCTION}

Field pea (Pisum arvense L.), often called "fodder pea, forage pea, winter pea, grey pea and Austrian winter pea", is the most important forage legume in all over the world. It is a cool-season annual-forage legume species (Sayar and Han, 2016). Obvious traces of the use of pea were found in many vestiges. They were from 9-10 thousand years ago and they were located in Anatolia, Iran, Greece and Palestine. However, the origin of field pea is near the Mediterranean area and Central Asia, according to Servet and Ate (2004), Ates (2012). It is a common forage legume in semi-arid regions, where the rainfall ranges from 350 to $650 \mathrm{~mm}$ for the Anatolia and Mediterranean area. It performs best on fertile, well-drained soils with high moisture holding capacity. Optimum growth is obtained on loams, silt loam, and well-textured soils of pH 6.0-7.5 (Ates, 2012). 
Field pea is used for grain, herbage, hay, pasture, green manure, silage (alone or with cereals); cover and rotational crop. Growing annual forage legumes such as field pea, Persian clover (Trifolium resupinatum L.), vetch (Vicia spp.) and lupine species (Lupinus spp.) in monoculture and field pea in mixture with cereals and other species provides, many benefits to forage grasses (Poaceae family)-based cropping systems: legumes biologically fix atmospheric nitrogen through symbiosis with Rhizobium bacteria, making it available to both the legumes and subsequent nonlegumes, thus reducing the need for inorganic nitrogen fertilizer inputs (Ates and Tekeli, 2005; Maćešic et al. 2007; Uher et al. 2008), decrease potential diseases, weeds and pest cycles established in continuous forage grasses and plant species of other families (Arslan et al. 2012). High forage production and quality for field pea depends on genotypes, environmental factors (rainfall, temperature etc.), sowing time, harvest stage, soil fertility and other cultivation techniques (Ates, 2016). It is rich in high quality protein. Although the levels of cell-wall components in field pea is lower than grasses, the cell walls of field pea is highly lignified and less available than grasses. It is also rich in phosphorus, calcium, potassium, magnesium and pro-vitamins and vitamins, especially pro-vitamin $A$ and ergocalciferol (vitamin $\mathrm{D}_{2}$ ). They made of field pea one of the best feeds for livestock feeding (Servet and Ate, 2004). Over $60 \%$ of the forage analysed had an ergocalciferol content of less than $600 \mathrm{IU}$ (international unit) $\mathrm{kg}^{-1}$ dry matter (DM), resulting in a severe risk of deficiency in domestic animals (Ballet et al. 2000). Havemose et al. (2004), Mercier et al. (2004) mentioned that the content of pro-vitamins in forage crops are thus important for the vitamin content as well as the oxidative stability of animal-derived foods such as dairy and meat products. Muhonen (2018) emphasized that these plants are produce pro-vitamins and vitamins, which are antioxidants, and their function is largely to protect plant and animal cells from oxidation and harmful products from the oxidation process.

The aim of this research was to determine the effect of different growth stages on ergocalciferol content, yield, some morphological characters and forage quality properties of six field pea genotypes.

\section{MATERIALS AND METHODS}

A field experiment was conducted during 2013-2015 (November-May) at one location (Kirklareli) in Thrace, Turkey. The experimental area was on ustalf soil, (phosphorus content of $58.7 \mathrm{~kg} \mathrm{ha}^{-1}$, potassium content of $487.2 \mathrm{~kg} \mathrm{ha}^{-1}$, organic matter of $1.12 \%$ and $\mathrm{pH}$ 6.7) at the Karamesutlu village $\left(41.25^{\circ} \mathrm{N}, 27.05^{\circ} \mathrm{E}\right)$ at $100 \mathrm{~m}$ a.s.l. with a total precipitation of $561.3 \mathrm{~mm}$ on average and an annual overall temperature of $13.2^{\circ} \mathrm{C}$.

Six field pea genotypes (Töre, Ateş, Taşkent, 16-K, DYK and $\mathrm{Kr}$ ) were planted in two-factor factorial Randomized Block Design with three replications. At each experiment, a basal fertilizer containing $\mathrm{N}$ and $\mathrm{P}$ (45 kg ha ${ }^{-1}$ ) was incorporated into the soil at the time of land preparation. At both years, each field pea genotypes was sown in plots of fifty rows, with a spacing of $26 \mathrm{~cm}$ and 40 $\mathrm{m}$ in length. The seeds were sown at a rate of $120 \mathrm{~kg} \mathrm{ha}^{-1}$ on November $11^{\text {th }}, 2013$ and November $01^{\text {st }}, 2014$. The plots were not irrigated after sown and harvest. In each year, main stem length $(\mathrm{cm})$, number of branches per plant, number of leaves per main stem and leaf length $(\mathrm{cm})$ were determined on twenty randomly selected plants at the pre-bud, $1 / 4$ bloom and full-bloom stages. Leaf length was determined on the leaf at third node of twenty plants. The central 10.1 square meter sections of plots were cut at $3 \mathrm{~cm}$ height from ground level for each genotypes at the three growth stages for herbage yield $\left(\mathrm{t} \mathrm{ha}^{-1}\right)$, and calculated. One cut was made in each year at the three growth stages such as pre-bud (first year: April 18, second year: April 15), 1/4 bloom (first year: April 30, 
second year: May 2) and full-bloom (first year: May 14, second year: May 16). Hay yield ( $\mathrm{t} \mathrm{ha}^{-1}$ ) for those samples were calculated by drying approximately $500 \mathrm{~g}$ samples at $55{ }^{\circ} \mathrm{C}$ for 48 hour followed by storage for a further day at room temperature (Ates and Tekeli, 2007; Ateş and Seren, 2020).

Besides, $600 \mathrm{~g}$ fresh herbage samples (Lindqvist et al. 2013) of the field pea genotypes were taken from each plot at all growth stages at $3 \mathrm{~cm}$ height from ground level before ergocalciferol analyses. Then, samples were sterilized in $2 \%$ sodium hypochlorite solution for 15 minute and washed in distilled water three times (Bajji et al. 2002; Tenikecier and Ates, 2018). The samples in sterile plastic bag for ergocalciferol analyses were frozen $\left(-20^{\circ} \mathrm{C}\right)$ immediately after sterilized (Lindqvist et al. 2013). The ergocalciferol contents $\left(\mu \mathrm{g} \mathrm{kg}^{-1}\right.$ in fresh matter (FM) basis) of freeze-dried samples were determined according to the methods described by Jäpelt et al. (2011). Hay samples were ground to small $(\leq 1 \mathrm{~mm})$ pieces and used for the other analyses. The samples were analyzed for $\mathrm{N}$ using procedures of the Association of Official Analytical Chemists (AOAC, 2019). Crude protein (CP) content (\%) of the samples were calculated by multiplying $\mathrm{N}$ contents by a coefficient of 6.25. The crude fiber (CF), acid detergent lignin (ADL), acid detergent fiber (ADF) and neutral detergent fiber (NDF) contents (\%) were determined by Weende and Van Soest methods (AOAC, 2019; Van Soest et al., 1991). All samples were analyzed in duplicate.

All data were analyzed statistically by analysis of variance using MSTAT-C software. The percentages were arcsine transformed before statistical analysis to ensure homogeneity of variance. Means of two years for treatments were compared using an ANOVA protected least significant difference (LSD) test.

\section{RESULTS AND DISCUSSIONS}

The results for the ergocalciferol content and some agronomic characters (some morphological characters and forage quality traits, herbage and hay yields) are given in Tables 1 to 3 . There were no significant differences at $P>0.05$ in the means of year, year $\mathrm{x}$ genotype and year $\mathrm{x}$ growth stage interactions when comparing between the years of investigation neither between the growth stages and field pea genotypes. Main stem length, herbage and hay yields of field pea were influenced significantly by genotype, growth stages and interaction effect of field pea genotype $\mathrm{x}$ growth stage. The maximum main stem length $(127.35-130.07 \mathrm{~cm})$, herbage yield $\left(50.12-50.33 \mathrm{t} \mathrm{ha}^{-1}\right)$ and hay yield (10.85-11.77 $\mathrm{t} \mathrm{ha}^{-1}$ ) were observed for field pea genotypes 'Ateş' and 'Töre' at full-bloom stage $(P>0.05)$. The means of the number of branches per plant, leaf length and number of leaves per main stem from field pea genotypes are significantly different by a LSD test at the $\mathrm{P}=0.05$ level of probability. The lowest leaf length $(22.08 \mathrm{~cm})$ and number of leaves per main stem (20.09) were found in field pea genotype '16-K', whereas number of branches per plant (6.42) had its highest in this same genotype. Plant height, number of branches per plant, main stem diameter, number of leaves per main stem, leaf length and number of leaflets per leaf are important traits that are used to determine herbage and hay yield (Tekeli and Ates, 2003). According to Murray and Swensen (1985), Tan et al. (2012), Sayar and Han (2016) emphasized that unfavorable ecological conditions led to the lower plant heights in field pea genotypes, since field pea is a typical cool season plant and its height increases under favorable, cool and moist conditions. Başbağ et al. (2001) reported yields of $17.11 \mathrm{t} \mathrm{ha}^{-1}$ and values of $3.59 \mathrm{t} \mathrm{ha}^{-1}$ in dry matter yields for field pea. Tekeli and Ates (2003); Servet and Ate (2004) obtained that the main stem length, number of branches per plant, leaf length, number of leaves per main stem and herbage yield ranged from 100.57-124.38 cm, $3.48-6.23,19.87-24.83 \mathrm{~cm}, 19.50-23.03$ and 14.17 to $28.23 \mathrm{t} \mathrm{ha}^{-1}$, respectively in field pea 


\section{Current Trends in Natural Sciences}

Vol. 9, Issue 17, pp. 06-14, 2020

https://doi.org/10.47068/ctns.2020.v9i17.001

Current Trends in Natural Sciences (on-line)

ISSN: 2284-953X

Current Trends in Natural Sciences (CD-Rom)

ISSN: 2284-9521

ISSN-L: 2284-9521

ISSN-L: 2284-9521

genotypes at full-bloom stage. Bilgili et al. (2010) reported forage yield produced by field pea genotypes ranged from 16070 to $35970 \mathrm{~kg} \mathrm{ha}^{-1}$ with an average protein concentration of $15.3 \%$ in field pea genotypes at full-bloom stage.

Table 1. Some morphological characters of six field pea genotypes (FPG) at different growth stages (GS) (means of two years)

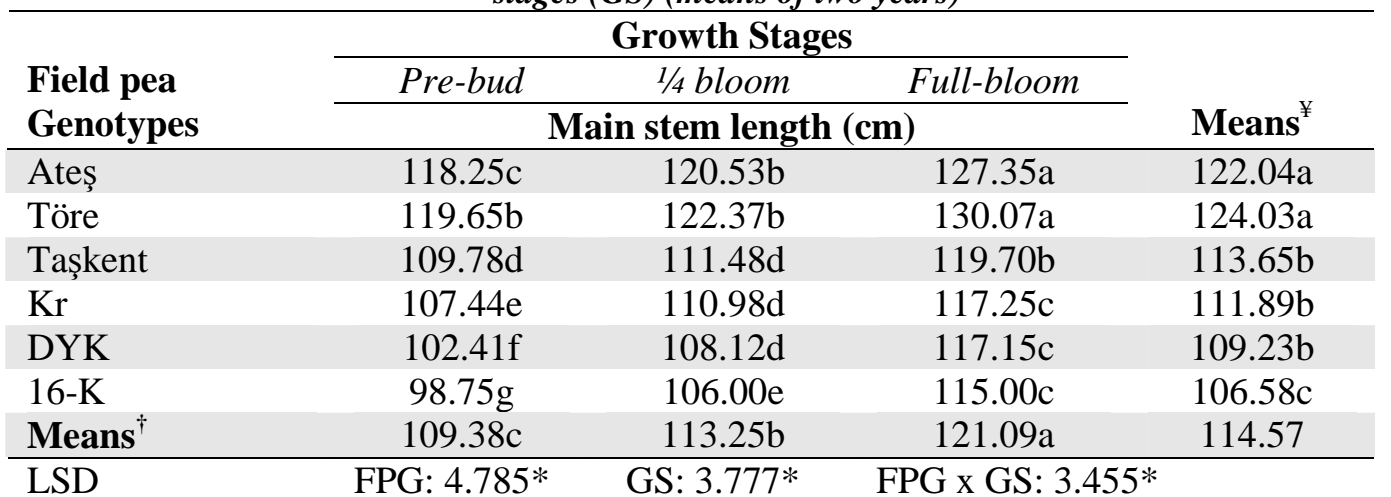

\begin{tabular}{lcccc}
\hline LSD & FPG: $4.785^{*}$ & GS: $3.777^{*}$ & FPG x GS: $3.455^{*}$ \\
\hline \multicolumn{5}{c}{ Number of branches per plant } \\
\hline Ateş & 4.28 & 4.30 & 4.33 & $4.30 \mathrm{~b}$ \\
Töre & 4.20 & 4.20 & 4.22 & $4.21 \mathrm{c}$ \\
Taşkent & 4.33 & 4.40 & 4.45 & $4.39 \mathrm{~b}$ \\
Kr & 3.20 & 3.22 & 3.25 & $3.22 \mathrm{e}$ \\
DYK & 3.51 & 3.55 & 3.55 & $3.54 \mathrm{~d}$ \\
16-K & 6.41 & 6.40 & 6.45 & $6.42 \mathrm{a}$ \\
Means & 4.32 & 4.35 & 4.38 & 4.35 \\
\hline LSD & FPG: $0.111^{*}$ & GS: NS & FPG x GS: NS & \\
\hline \multicolumn{5}{c}{ Leaf length (cm) } \\
\hline Ateş & 25.10 & 25.07 & 25.11 & $25.09 \mathrm{a}$ \\
Töre & 25.00 & 25.02 & 25.09 & $25.04 \mathrm{a}$ \\
Taşkent & 24.00 & 24.10 & 24.12 & $24.07 \mathrm{a}$ \\
Kr & 23.49 & 23.50 & 23.56 & $23.52 \mathrm{~b}$ \\
DYK & 23.79 & 23.88 & 24.00 & $23.89 \mathrm{a}$ \\
16-K & 22.00 & 22.13 & 22.12 & $22.08 \mathrm{c}$ \\
Means & 23.90 & 23.95 & 24.00 & 23.95 \\
\hline LSD & FPG: $1.232^{*}$ & GS: NS & FPG x GS: NS &
\end{tabular}

\begin{tabular}{lcccc}
\hline Ateş & 22.98 & 23.10 & 23.07 & $23.05 \mathrm{a}$ \\
Töre & 22.97 & 23.10 & 23.00 & $23.02 \mathrm{a}$ \\
Taşkent & 23.05 & 23.15 & 23.10 & $23.10 \mathrm{a}$ \\
Kr & 22.10 & 22.08 & 22.12 & $22.10 \mathrm{~b}$ \\
DYK & 22.45 & 22.56 & 22.75 & $22.59 \mathrm{a}$ \\
$16-\mathrm{K}$ & 20.12 & 19.97 & 20.17 & $20.09 \mathrm{c}$ \\
Means & 22.28 & 22.33 & 22.37 & 22.33 \\
\hline LSD & FPG: $0.551^{*}$ & GS: NS & FPG x GS: NS & \\
\hline
\end{tabular}

$* P<0.05$, NS: $P>0.05,{ }^{*}$ The means different growth stages of with different letter for the same row are significantly different. ${ }^{\text {F}}$ Field pea genotypes means with different letter of the column are significantly different. 


\section{Current Trends in Natural Sciences}

Vol. 9, Issue 17, pp. 06-14, 2020

https://doi.org/10.47068/ctns.2020.v9i17.001

Current Trends in Natural Sciences (on-line)

Table 2. The ergocalciferol and crude protein contents, herbage and hay yields of six field pea genotypes (FPG) at different growth stages (GS) (means of two years)

\begin{tabular}{|c|c|c|c|c|}
\hline \multirow{3}{*}{$\begin{array}{l}\text { Field pea } \\
\text { Genotypes }\end{array}$} & \multicolumn{3}{|c|}{ Growth Stages } & \multirow[b]{3}{*}{ Means $^{\neq}$} \\
\hline & Pre-bud & $1 / 4$ bloom & Full-bloom & \\
\hline & \multicolumn{3}{|c|}{ Herbage yield $\left(\mathrm{t} \mathrm{ha}^{-1}\right)$} & \\
\hline Ateş & $38.75 \mathrm{c}$ & $46.41 b$ & $50.33 a$ & $45.16 \mathrm{a}$ \\
\hline Töre & $38.41 \mathrm{c}$ & $44.88 b$ & $50.12 \mathrm{a}$ & $44.47 \mathrm{a}$ \\
\hline Taşkent & $35.20 \mathrm{~d}$ & $40.68 c$ & $44.56 b$ & $40.15 b$ \\
\hline $\mathrm{Kr}$ & $34.89 d$ & $40.21 \mathrm{c}$ & 40.23 & $38.44 b$ \\
\hline DYK & $32.85 d$ & $37.74 \mathrm{c}$ & $38.59 \mathrm{c}$ & $36.39 b$ \\
\hline $16-K$ & $29.77 \mathrm{e}$ & $35.22 \mathrm{~d}$ & $35.66 \mathrm{~d}$ & $33.55 \mathrm{c}$ \\
\hline Means $^{\dagger}$ & $34.98 \mathrm{c}$ & $40.86 b$ & $43.25 \mathrm{a}$ & 39.69 \\
\hline LSD & FPG: $4.313 *$ & GS: $2.711^{*}$ & FPG x GS: $3.612 *$ & \\
\hline \multicolumn{5}{|c|}{ Hay yield $\left(\mathrm{t} \mathrm{ha}^{-1}\right)$} \\
\hline Ateş & $7.88 \mathrm{c}$ & $9.71 \mathrm{~b}$ & $10.85 a$ & $9.48 \mathrm{a}$ \\
\hline Töre & $7.85 \mathrm{c}$ & $9.88 b$ & $11.77 \mathrm{a}$ & $9.83 a$ \\
\hline Taşkent & $7.13 \mathrm{~d}$ & $8.43 c$ & $9.55 b$ & $8.37 \mathrm{~b}$ \\
\hline $\mathrm{Kr}$ & $6.58 \mathrm{~d}$ & $8.00 \mathrm{c}$ & $8.78 b$ & $7.79 b$ \\
\hline DYK & $5.69 \mathrm{e}$ & $7.05 \mathrm{~d}$ & $7.85 \mathrm{c}$ & $6.86 c$ \\
\hline $16-\mathrm{K}$ & $4.85 \mathrm{e}$ & $5.89 \mathrm{e}$ & $6.45 d$ & $5.73 c$ \\
\hline Means & $6.66 c$ & $8.16 b$ & $9.21 \mathrm{a}$ & 8.01 \\
\hline LSD & FPG: $1.398 *$ & GS: $1.042 *$ & FPG x GS:1.223* & \\
\hline \multicolumn{5}{|c|}{$\mathrm{CP}(\%)$} \\
\hline Ateş & 19.98 & 19.00 & 18.67 & 19.22 \\
\hline Töre & 20.22 & 19.07 & 18.56 & 19.28 \\
\hline Taşkent & 20.05 & 19.10 & 18.57 & 19.24 \\
\hline $\mathrm{Kr}$ & 20.12 & 19.33 & 18.45 & 19.30 \\
\hline DYK & 19.89 & 18.88 & 17.95 & 18.91 \\
\hline $16-K$ & 18.57 & 19.07 & 18.00 & 18.55 \\
\hline Means & $19.81 \mathrm{a}$ & $19.08 \mathrm{a}$ & $18.37 \mathrm{~b}$ & 19.08 \\
\hline LSD & FPG: NS & GS: $1.031 *$ & FPG x GS: NS & \\
\hline \multicolumn{5}{|c|}{ Ergocalciferol $\left(\mu \mathrm{g} \mathrm{kg}^{-1}\right.$ in FM $)$} \\
\hline Ateş & 8.50 & 8.67 & 9.70 & 8.96 \\
\hline Töre & 8.00 & 8.42 & 9.55 & 8.66 \\
\hline Taşkent & 8.12 & 8.21 & 9.60 & 8.64 \\
\hline $\mathrm{Kr}$ & 7.90 & 7.95 & 9.12 & 8.32 \\
\hline DYK & 8.33 & 8.78 & 9.00 & 8.70 \\
\hline $16-\mathrm{K}$ & 7.45 & 7.68 & 9.00 & 8.04 \\
\hline Means & $8.05 b$ & $8.29 b$ & $9.33 \mathrm{a}$ & 8.55 \\
\hline LSD & FPG: NS & GS: $0.889 * *$ & FPG x GS: NS & \\
\hline
\end{tabular}

$* P<0.05, * * P<0.01$, NS: $P>0.01$ and $0.05,{ }^{*}$ The means different growth stages of with different letter for the same row are significantly different. ${ }^{¥}$ Field pea genotypes means with different letter of the column are significantly different.

Tekeli and Ateş (2011) mentioned that field pea grew to a height of $400 \mathrm{~cm}$ under the suitable ecological and cultivation conditions, whereas Kosev et al. (2013) reported this value to be only $30.72-76.10 \mathrm{~cm}$ in spring field pea. Kavut et al. (2016) determined that the dry matter yields of the forage pea varieties varied between 7.27 and $8.90 \mathrm{t} \mathrm{ha}^{-1}$ in $20 \mathrm{~cm}$ row spacing in the Aegean region. The present results were similar to those reported by these researchers.

Considering the chemical composition of dried forage samples, growth stages changed ergocalciferol content and other some quality traits of forage in field pea genotypes. There are no reports on the ergocalciferol content of field pea herbage. Full-bloom stage showed the highest 


\section{Current Trends in Natural Sciences}

Vol. 9, Issue 17, pp. 06-14, 2020

https://doi.org/10.47068/ctns.2020.v9i17.001

Current Trends in Natural Sciences (on-line)

ISSN: 2284-953X

Current Trends in Natural Sciences (CD-Rom)

ISSN: 2284-9521

ISSN-L: 2284-9521

ISSN-L: 2284-9521

ergocalciferol (9.33 $\mathrm{g} \mathrm{kg} \mathrm{k}^{-1}$ in FM), CF (20.63\%), NDF (41.46 \%), ADF (30.54\%) and ADL (5.84 $\%)$ contents between the other growth stages $(P<0.01)$, whereas CP $(18.37 \%)$ had its lowest content at this same growth stage $(P<0.05)$ (Table 2 and 3$)$.

Table 3. Some plant cell walls fiber fractions (\% in DM) of six field pea genotypes (FPG) at different growth stages (GS) (means of two years)

\begin{tabular}{|c|c|c|c|c|}
\hline \multirow{3}{*}{$\begin{array}{l}\text { Field pea } \\
\text { Genotypes }\end{array}$} & \multicolumn{3}{|c|}{ Growth Stages } & \multirow[b]{3}{*}{ Means } \\
\hline & Pre-bud & $1 / 4$ bloom & Full-bloom & \\
\hline & \multicolumn{3}{|c|}{$\mathrm{CF}$} & \\
\hline Ateş & 18.88 & 20.74 & 21.45 & 20.36 \\
\hline Töre & 17.89 & 19.87 & 20.31 & 19.36 \\
\hline Taşkent & 18.33 & 19.55 & 19.97 & 19.28 \\
\hline $\mathrm{Kr}$ & 17.95 & 19.32 & 20.56 & 19.28 \\
\hline DYK & 17.77 & 18.89 & 21.00 & 19.22 \\
\hline $16-\mathrm{K}$ & 18.05 & 19.66 & 20.49 & 19.40 \\
\hline Means $^{\dagger}$ & $18.15 \mathrm{c}$ & $19.67 \mathrm{~b}$ & $20.63 a$ & 19.48 \\
\hline \multirow[t]{2}{*}{ LSD } & FPG: NS & GS: $0.951 * *$ & FPG x GS: NS & \\
\hline & \multicolumn{3}{|c|}{ NDF } & \\
\hline Ateş & 38.66 & 40.05 & 41.33 & 40.01 \\
\hline Töre & 37.98 & 40.00 & 41.28 & 39.75 \\
\hline Taşkent & 38.12 & 40.56 & 41.31 & 40.00 \\
\hline $\mathrm{Kr}$ & 38.22 & 40.38 & 41.87 & 40.16 \\
\hline DYK & 38.61 & 40.11 & 41.68 & 40.13 \\
\hline $16-K$ & 37.91 & 39.95 & 41.31 & 39.72 \\
\hline Means & $38.25 \mathrm{c}$ & $40.18 b$ & $41.46 \mathrm{a}$ & 39.96 \\
\hline \multirow[t]{2}{*}{ LSD } & FPG: NS & GS: $0.933^{* *}$ & FPG x GS: NS & \\
\hline & \multicolumn{3}{|c|}{ ADF } & \\
\hline Ateş & 28.77 & 29.56 & 30.66 & 29.66 \\
\hline Töre & 27.97 & 28.97 & 30.13 & 29.02 \\
\hline Taşkent & 27.98 & 29.00 & 30.55 & 29.18 \\
\hline $\mathrm{Kr}$ & 28.22 & 29.17 & 30.45 & 29.28 \\
\hline DYK & 28.00 & 29.33 & 30.44 & 29.26 \\
\hline $16-\mathrm{K}$ & 28.64 & 29.44 & 31.00 & 29.69 \\
\hline Means & $28.26 \mathrm{c}$ & $29.25 b$ & $30.54 \mathrm{a}$ & 29.35 \\
\hline \multirow[t]{2}{*}{ LSD } & FPG: NS & GS: $0.888^{* *}$ & FPG x GS: NS & \\
\hline & \multicolumn{3}{|c|}{ ADL } & \\
\hline Ateş & 4.86 & 5.10 & 5.84 & 5.27 \\
\hline Töre & 4.77 & 5.05 & 5.88 & 5.23 \\
\hline Taşkent & 4.76 & 4.98 & 5.80 & 5.18 \\
\hline $\mathrm{Kr}$ & 4.81 & 5.00 & 5.82 & 5.21 \\
\hline DYK & 4.86 & 4.99 & 5.85 & 5.23 \\
\hline $16-K$ & 4.83 & 5.04 & 5.84 & 5.24 \\
\hline Means & $4.82 b$ & $5.03 \mathrm{~b}$ & $5.84 a$ & 5.23 \\
\hline LSD & FPG: NS & GS: $0.800^{* *}$ & FPG x GS: NS & \\
\hline
\end{tabular}

$* * P<0.01$, NS: $P>0.01$ and $0.05,{ }^{\dagger}$ The means different growth stages of with different letter for the same row are significantly different.

Ergocalciferol can be found in plants contaminated with fungi. Conversion to vitamin $\mathrm{D}_{2}$ occurs by sun-exposure of the plant material during growth and in the curing process (Jäpelt and Jakobsen, 2013). Many factors that influence the ergocalciferol content of forage crops during growth, development, harvesting and storage include: growth stage, leaf/stem ratio; climatic and edaphic factors, such as geographic location and topographic properties, seasonal and yearly variation, 
illuminance-associated diurnal variation, soil traits; biotic damage; conservation methods of herbage/hay (dehydration, ensiling, drying and etc.) and storage conditions of forage. Besides, mineral and protein values in forage crops depends on soil traits and available amounts of elements in it, fertilization and other cultivation applies, climatic conditions as well as plant growth stages and different morphological parts of crops. On the other hand, fiber content of forage crop species are affected above-mentioned many factors (Tenikecier and Ates, 2018). Young plant cells have the primary cell wall, but also the secondary cell wall occurs with maturing. This causes mature plants to be the more fibrous (Bajji at al. 2004). ADF, NDF and ADL contents increased with advancing plant growth. This could be explained by the decrease in the proportion of leaves and increase of the proportion of stems with advanced maturity. The trend in ADL, ADF and NDF contents with increasing maturity is normally the reverse of protein (Rebole at al. 2004; Yuksel and Turk, 2019). Forage grasses are higher in NDF, ADF and ADL at a given stage of growth than forage legumes. The quality of forage crops is best estimated by their potential dry matter intake and dry matter digestibility, which are determined by the NDF and ADF fractions, respectively. Both NDF and ADF increase as the plant matures causing a decline in the quality of the forage (Linn and Kuehn, 1997; Ates and Tenikecier, 2019). Horst et al. (1984) researched that the isolation and identification of ergocalciferol and cholecalciferol (vitamin $\mathrm{D}_{3}$ ) from alfalfa (Medicago sativa L.). They examined sun-cured field grown alfalfa and determined $48 \mu \mathrm{g} \mathrm{kg}^{-1}$ ergocalciferol. Jakobsen and Saxholt (2009) stated that milk from dairy cows contains a significant although low amount of ergocalciferol, which is expected to derive from grass and hay. Jäpelt et al. (2011) also found an effect of forage maturity on the ergocalciferol content, and further described an effect of humidity, precipitation, and UVB radiation on the ergocalciferol content of forage. They stated that the ergocalciferol content was maximum $2 \%$ of the ergosterol content, which might indicate that not ultraviolet $\mathrm{B}$, but rather ergosterol concentration is the limiting factor in ergocalciferol production in plants. Kohler et al. (2013) determined that the ergocalciferol content was greater in the lowland pasture grass compared to the alpine pasture grass. They found that ergocalciferol contents of forage samples in alpine pasture grass at early summer, alpine pasture grass at late summer, lowland pasture grass at early summer and lowland pasture grass at late summer ranging from $20.6 \mu \mathrm{g} \mathrm{kg}^{-1}$ DM, $32.0 \mu \mathrm{g} \mathrm{kg}^{-1} \mathrm{DM}, 52.4 \mu \mathrm{g} \mathrm{kg}^{-1} \mathrm{DM}$ and $73.6 \mu \mathrm{g} \mathrm{kg}^{-1} \mathrm{DM}$, respectively. Our results for ergocalciferol content are significantly lower to those reported by these researchers. This may be because ergocalciferol content was analyzed in fresh matter. Tenikecier and Ates (2019) mentioned that the total protein content is inversely related to growth stages of the forage crops, nevertheless, protein of forage crops could be quite variable among species and their genotypes. Yuksel and Turk (2019) reported that the dry matter yield, CP, NDF and ADF contents ranged from 5.91-8.58 $\mathrm{t} \mathrm{ha}^{-1}$, 17.36-19.05\%, 35.80-39.98 \% and 27.00 to $29.20 \%$, respectively in field pea at different harvesting stages. They emphasized that the maturity stage at harvest is the most important factor determining forage quality. Ates et al. (2020) obtained that the highest $\alpha$-tocopherol content were obtained in the field pea variety 'Ateş' $\left(29.7 \mathrm{mg} \mathrm{kg}^{-1}\right)$ and variety 'Töre' $\left(29.0 \mathrm{mg} \mathrm{kg}^{-1}\right)$ at pre-bud stage. They found that the lowest $\beta$-carotene content $\left(29.7-29.9 \mathrm{mg} \mathrm{kg}^{-1}\right)$ in field pea at $1 / 2$ bloom and full bloom stages.

\section{CONCLUSIONS}

It was concluded that ergocalciferol (vitamin $\mathrm{D}_{2}$ ), $\mathrm{CP}, \mathrm{CF}, \mathrm{ADF}, \mathrm{NDF}$ and ADL contents of field pea genotypes were affected by growth stages. Main stem length, herbage and hay yields of field pea were influenced significantly by genotype, growth stages and interaction effect of field pea 


\section{Current Trends in Natural Sciences}

Vol. 9, Issue 17, pp. 06-14, 2020

https://doi.org/10.47068/ctns.2020.v9i17.001

Current Trends in Natural Sciences (on-line)

ISSN: 2284-953X

Current Trends in Natural Sciences (CD-Rom)

ISSN: 2284-9521

ISSN-L: 2284-9521

ISSN-L: 2284-9521

genotype $x$ growth stage. The means of the number of branches per plant, leaf length and number of leaves per main stem from field pea genotypes are significantly different. According to ergocalciferol content, forage yield and other quality properties, genotypes 'Ateş' and 'Töre' can be sown and cut at full-bloom stage in the Thrace and other regions of Turkey, and probably in similar subtropical conditions.

\section{REFERENCES}

AOAC. (2019). Official Methods of Analysis of AOAC International. $21^{\text {st }}$ Ed, Association of Official Analytical Chemists, USA.

Arslan, B., Ates, E., Coskuntuna, L. (2012). Forage yield and some quality properties of safflower (Carthamus tinctorius L.)-fodder pea (Pisum arvense L.) mixtures, as affected by sowing rates in Thrace region, Turkey. Romanian Agric Res, 29, 255-260.

Arzani, H., Zohdi, M., Fish, E., Zahedi Amiri, G.H., Nikkhah, A., Wester, D. (2004). Phenological effects on forage quality of five grass species. J Range Manage, 57, 624-629.

Ates, E. (2012). Yem Bezelyesi [Field Pea]. Hasad Hayvancilik, 28 (329), 62-63.

Ates, E. (2016). Determining drought tolerance of new fodder pea and Persian clover genotypes at the germination and early seedling stages. Fresenius Environmental Bulletin, 25, 6020-6029.

Ates, E., Tekeli, A.S., 2005. Forage quality and tetany potential of orchardgrass (Dactylis glomerata L.) and white clover (Trifolium repens L.) mixtures. Cuban J Agric Sci, 39, 97-102.

Ates, E., Tekeli, A.S. (2007). Salinity tolerance of Persian clover (Trifolium resupinatum L. var. majus Boiss.) lines at germination and seedling stages. World J Agric Sci, 3, 71-79.

Ates, E., Tenikecier, H.S. (2019). Hydrocyanic acid content, forage yield and some quality features of two sorghumSudan grass hybrid cultivars under different nitrogen doses in Thrace, Turkey. Current Trends in Natural Sciences, 8, 55-62.

Ates, E., Tenikecier, H.S., Ozkan, U. (2020). The dry matter yield, $\alpha$-tocopherol, $\beta$-carotene and some mineral contents in fodder pea (Pisum arvense L.) varieties at different growth stages. Comptes rendus de l'Académie bulgare des Sciences, 73, 579-586.

Ateş, E., Seren, O.A. (2020). Determination of forage yield and quality of blue melilot (Melilotus caeruleus (L.) Desr.) at different growth stages under Edirne ecological conditions. Ege Üniv Ziraat Fak Derg, 57, 111-117.

Bajji, M., Kinet, J.M., Lutt, S. (2002). Osmotic and ionic effects of $\mathrm{NaCl}$ on germination, early seedling growth and ions content of Atriplex halimus (Chenopodiaceae). Can J Bot, 80, 297-304.

Ballet, N., Robert, J.C., Williams, P.E.V. (2000). Vitamins in forages. In: Givens DI, Owen E, Axford RFE, Omed HM (eds), Forage evaluation in ruminant nutrition, CABI Publishing, UK.

Basbag, M., Saruhan, V., Gül, I. (2001). An investigation on adaptation of some annual legumes forage crops under Diyarbakir conditions. Proceedings of $4^{\text {th }}$ Turkey Field Crops Congress, 17-21 Sept., Tekirdag, Turkey, p. 169.

Bilgili, U., Uzun, A., Sincik, M., Yavuz, M., Aydınoğlu, B., Çakmakçı, S., Geren, H., Avcıoğlu, R., Nizam, İ., Tekeli, A.S., Gül, İ., Anlarsal, E., Yüzel, C., Avcı, M., Acar, Z., Ayan, İ., Üstün, A., Açıkgöz, E. (2010). Forage yield and lodging traits in peas (Pisum sativum L.) with different leaf types. Turk J Field Crops, 15, 50-53.

Havemose, M.S., Weisbjerg, M.R., Bredie, W.L.P., Nielsen, J.H. (2004). Influence of feeding different types of roughage on the oxidative stability of milk. Int Dairy J, 14, 563-570.

Horst, R.L., Reinhardt, T.A., Russell, J.R., Napoli, J.L. (1984). The isolation and identification of vitamin $\mathrm{D}_{2}$ and vitamin $\mathrm{D}_{3}$ from Medicago sativa (alfalfa plant). Arch Biochem Biophys, 231, 67-71.

Jakobsen, J., Saxholt, E. (2009). Vitamin D metabolites in bovine milk and butter. J Food Comp Anal, 22, $472-478$.

Jäpelt, R.B., Didion, T., Smedsgaard, J., Jacobsen, J. (2011). Seasonal variation of provitamin $\mathrm{D}_{2}$ and vitamin $\mathrm{D}_{2}$ in perennial ryegrass (Lolium perenne L.). J Agric Food Chemistry, 59, 10907-10912.

Jäpelt, R.B., Jacobsen, J. (2013). Vitamin D in plants: a review of occurrence, analysis, and biosynthesis. Frontiers in Plant Science, 4 (Article 136), 1-20.

Kavut, Y.T., Celen, A.E., Cibik, E.S., Urtekin, M.A. (2016). A research on the yield and some yield characteristics of some field pea (Pisum arvense L.) varieties grown in different row spacing in Aegean region conditions. J Cent Res Inst Field Crops, 25, 225-229.

Kohler, M., Leiber, F., Willems, H., Merbold, L., Liesegang, A. (2013). Influence of altitude on vitamin D and bone metabolism of lactating sheep and goats. J Anim Sci, 91, 5259-5268.

http://www.natsci.upit.ro

*Corresponding author, E-mail address: ertan_ates@hotmail.com 


\section{Current Trends in Natural Sciences}

Vol. 9, Issue 17, pp. 06-14, 2020

https://doi.org/10.47068/ctns.2020.v9i17.001

Current Trends in Natural Sciences (on-line)

ISSN: 2284-953X

Current Trends in Natural Sciences (CD-Rom)

ISSN: 2284-9521

ISSN-L: 2284-9521

ISSN-L: 2284-9521

Kosev, V., Pachev, I., Mikić, A. (2013). Assessing the breeding value of nine spring field pea (Pisum sativum L.) cultivars. Plant Breeding and Seed Science, 68, 55-65.

Lindqvist, H., Nadeau, E., Jensen, S.K., Søegaard, K. (2013). $\alpha$-Tocopherol and $\beta$-carotene contents of forage species in a four-cut system. Grass and Forage Sci, 69, 356-364.

Linn, J., Kuehn, C. (1997). The effects of forage quality on performance and cost of feeding lactating dairy cows. Western Canadian Dairy Seminar 1997 Proceedings, Department of Agricultural, Food \& Nutritional Science 410 Agriculture/Forestry Centre University of Alberta Edmonton, AB, Canada.

Maćešic, D., Uher, D., Sikora, S., Blažinkov, M., Štafa, Z. (2007). Yield and height of alfalfa (Medicago sativa L.) effected by Rhizobial inoculation. Cereal Research Communications, 35, 737-740.

Mercier, Y., Gatellier, P., Renerre, M. (2004). Lipid and protein oxidation in vitro, and antioxidant potential in meat from Charolais cows finished on pasture or mixed diet. Meat Sci, 66, 467-473.

Muhonen, S. (2018). Vitamin E and A in forage for horses. Retrieved January 25, 2020, from http://www.forageforhorses.com/en

Murray, G.A., Swensen, J.B. (1985). Seed yield of Austrian winter field peas intercropped with winter cereals. Agron J, 77, 913-916.

Rebole, A., Alzueta, C., Ortiz, L.T., Barro, C., Rodriguez, M.L., Caballero, R. (2004). Yields and chemical composition of different parts of the common vetch at flowering and at two seed filling stages. Spanish J Agric Res, 2, 550557.

Sayar, M.S., Han, Y. (2016). Forage yield performance of forage pea (Pisum sativum spp. arvense L.) genotypes and assessment using GGE biplot analysis. J Agr Sci Tech, 18, 1621-1634.

Servet, A., Ate, E. (2004). Determination of some agricultural characters in field pea (Pisum arvense L.) lines at Tekirdağ (Turkey) ecological conditions. Cuban J Agric Sci, 38, 313-316.

Tan, M., Koc, A., Dumlu Gul, Z. (2012). Morphological characteristics and seed yield of East Anatolian local forage pea (Pisum sativum ssp. arvense L.) ecotypes. Turk J Field Crop, 17, 24-30.

Tekeli, A.S., Ates, E. (2003). Yield and its components in field pea (Pisum arvense L.) lines. J Cent Eur Agric, 4, 313318.

Tekeli, A.S., Ateş, E. (2011). Baklagil Yem Bitkileri [Forage Legumes]. Sevil Grafik Tasarim ve Cilt Evi, Tekirdag, Turkey, pp 166-167.

Tenikecier, H.S., Ates, E. (2018). Chemical composition of six grass species (Poaceae sp.) from protected forest range in Northern Bulgaria. Asian J Applied Sci, 11, 71-75.

Tenikecier, H.S., Ates, E. (2019). Effect of altitude on morphological and nutritive characteristics of orchard grass (Dactylis glomerata L.) collected from natural flora of Ganos Mountain in Thrace region, Turkey. Range Mgmt Agroforestry, 40, 286-292.

Uher, D., Štafa, Z., Sikora, S., Blažinkov, M. (2008). Yield and quality of forage type pea lines and wheat mixtures. VII. Alps-Adria Scientific Workshop, Stara Lesna, Slovakia.

Van Soest, P.J., Robertson, J.B., Lewis, B.A. (1991). Methods for dietary fibre, neutral detergent fibre, and nonstarch polysaccharides in relation to animal nutrition. J Dairy Sci, 74, 3583-3597.

Yuksel, O., Turk, M. (2019). The effects of phosphorus fertilization and harvesting stages on forage yield and quality of pea (Pisum sativum L.). Fresenius Environmental Bulletin, 28, 4165-4170. 